\title{
Van-e és mérhető-e az oktatási innováció hazánkban?
}

\author{
Fazekas Ágnes
}

az Eötvös Loránd Tudományegyetem Pedagógiai és Pszichológiai Karának tudományos segédmunkatársa

fazekasagnes@caesar.elte.hu

DOI: 10.37205/TEL-hun.2019.1-2.08

„Magyarországon nem lehet iskolai innovációt kutatni.” - mondta indulatosan egy oktatáskutató kollégám, amikor egy az iskolai fejlesztések születését és terjedését vizsgáló kutatás tervét vázoltam neki. A beszélgetés nagyjából öt évvel az oktatás világára irányuló centralizációs intézkedések elindulása után zajlott. Ekkor az iskolák mindennapos müködéséről professzionális szinten gondolkodók egy komoly hányada már úgy látta, hogy az intézmények gyakorlata a szabályozási kereteknek megfelelően alakul, drasztikusan uniformizálódik. Egy másik csoport - amelyhez én magam is tartoztam - az iskolák belső működéséről másképp vélekedett. Utóbbiak megközelítése szerint az intézmények és pedagógusaik nap mint nap számos apróbb - vagy akár jelentősebb - új megoldással kísérleteznek. Függetlenül attól, hogy erre kapnak-e külső támogatást, engedélyt, vagy sem. Mindez a szakma természetéből, az osztálytermi folyamatok nehezen kiszámítható jellegéből adódik. A megközelítések különbözősége logikusan veti fel azt az átfogó kérdést, hogy vajon végezhető-e a pedagógiai munka újítások, helyi kísérletezések nélkül.

A kutatás végül elindult, ${ }^{1}$ eredményeképpen pedig láthatóvá vált, hogy a hazai iskolák gazdag és széles spektrumú innovatív megoldásokkal dolgoznak. Természetesen itthon is hatalmas különbségek vannak aközött, hogy egy-egy iskola képes-e hatékonyan segíteni diákjai kognitív és affektív fejlődését, illetve pedagógusai tudnak-e ennek megfelelő újszerű pedagógiai megoldásokat létrehozni. Mindazonáltal úgy látom, kellő figyelemmel az intézmények mindegyikében - még a leginkább megkövesedett módon múködőkben is - fel lehet fedezni olyan újszerü, kreatív megoldásokat, amelyek méltók lehetnek a szakmai figyelemre. Ebben kétségkívül jelentős szerepe van a pedagógusszakma régóta ismert és fentebb is em-

${ }^{1}$ INNOVA kutatás (OTKA 115857 ) https://nevtud.ppk.elte.hu/content/innova-kutatas.t.6078?m=2637 Letöltés ideje: 2019. 12. 09. 
lített azon sajátosságának, miszerint az osztálytermi folyamatokat olyan előre nem kalkulálható helyzetek formálják, melyek kezelése kreatív válaszokat igényel. Ugyanakkor fontos azt is látni, hogy az innovációk csupán egy része irányul e helyzetek kezelésére. Számos újszerű megoldás az osztálytermen kívüli múködést támogatja: ilyenek például a szervezet belső menedzselésére vagy a partnerekkel (szülőkkel) való kapcsolattartásra irányuló megoldások. Mindez nem meglepő, a szervezeti működés is olyan komplex rendszerként azonosítható, amelyben kiemelt szerephez jut a nehezen kiszámítható problémák kezelésére való képesség.

Emellett az új megoldások létrehozásában fontos szerepet kapnak az olyan driverek is, amelyek nem a problémák kezeléséhez kötődnek. A kísérletezések mögött sok esetben általános modernizálási szándék áll, mely a versenyképesség megerősítését célozza. Ha kilépünk a nemzeti keretekből, láthatjuk, hogy az országok közötti gazdasági és humánerőforrás-kihasználási versengés közvetlenül ösztönzi az új és igazolhatóan hatékony megoldások létrehozását. Az innováció a gazdaság talán legmeghatározóbb hívószava lett, mely szervesen beépült a cégek kommunikációs gyakorlatába és a fogyasztók hétköznapi szóhasználatába is. Az oktatási innovációk létrehozására is komoly figyelem irányul, jól megmutatkozik ez többek között az Európai Unió oktatásfejlesztési gyakorlatában, vagy az OECD oktatási innovációk területén végzett kutatásaiban. ${ }^{2}$

A fent említett kutatás és annak időről időre megjelenő eredményei egy másik szakmai kérdést, illetve annak nyomán kialakuló konfliktust is bevonzottak a feltáró munkát végzők életébe. A kérdés az innovációk jóságának problémáját feszegette, mely problématerület természetesen nem csupán, vagy nem elsősorban a hazai gondolkodás sajátja. A kapcsolódó viták középpontjában az a kérdés állt, vajon értelmezhetőek-e az új iskolai megoldások olyan képződményekként, amelyek az intézmények minőségi működését támogatják. Azok, akik ezt komolyan kétségbe vonták, az iskolákban eluralkodó kaotikus helyzetek megjelenését vizionálták. Utóbbi dilemma kezelését a kutatócsoport egy olyan innováció-definíció$\mathrm{val}^{3}$ kezelte, amely tekintettel van az újítás és a pedagógiai eredményesség kapcsolatára. Azaz azokat az újszerű megoldásokat neveztük helyi innovációnak,

${ }^{2}$ Lásd például Innovative Learning Environments (ILE) projekt

http://www.oecd.org/education/ceri/innovativelearningenvironments.htm Measuring Innovation in Education: https://www.oecd.org/education/measuring-innovation-in-education.htm Letöltés ideje: 2019.

12. 09.

${ }^{3} \mathrm{Az}$ innováció értelmezésének számos formáját ismerjük, lásd például Godin, Benoit (2015): Innovation Contested. The Idea of Innovation Over the Centuries. Routledge. 
amelyek részben, vagy egészben az iskola szintjén születtek, és amelyek képesek voltak hozzájárulni a pedagógiai munka vagy a szervezeti müködés valamilyen értelemben vett eredményességéhez. Itt azonban érdemes megjegyezni: az eredményességet nem javító, akár kudarcként megélt innovációkhoz vezető kísérletezési út is számos olyan tanulási elemet tartalmazhat, amely hosszabb távon támogatja a hatékony tanulásszervezési eljárások kidolgozását.

Mindemellett a múködő gyakorlatokat bomlasztó innovációk okozta kaotikus állapotok pragmatikus oldalára is érdemes pár szóval kitérnünk. Meglátásom szerint az ilyen állapotok kialakulásának veszélyét jelentősen csökkenti, hogy az új megoldások burjánzása azokban a szervezetekben lehet jellemző, ahol a kultúra és a rutinok támogatják a pedagógusok tanulását, szakmai kísérletezését. Ezek a többnyire tanulószervezetként is azonosítható iskolák jellemzően képesek kezelni az újításokkal keletkezo időszakos „zürzavart”, a rutinok elhagyásával járó ideiglenes regressziós állapotokat és az eredményesség növekedését hosszabb távon igazolhatóan támogató innovációk kiszürését. Természetesen ismerünk olyan főáramtól eltérő oktatási megoldások irányában mélyen elkötelezett iskolákat, amelyek innovatív működése évtizedek után sem jár együtt a mérhető eredmények növekedésével. Azonban itt sem a kaotikus müködés az, ami dominál. Csupán olyan pedagógiai megoldások elhivatott gyakorlóiról van szó, amelyek nyomán fejlődő készségek kívül esnek azokon a kompetenciaterületeken, amelyekre a tanulói eredményeségmérések irányulnak. Mindazonáltal ezeknek az intézményeknek a müködése rávilágít arra a különösen fontos dilemmára, hogy tekinthető-e innovációnak - a pedagógiai folyamatok jobbitását szolgáló újításnak - az olyan gyakorlat, amely eredményességét mérési eredmények nem támasztják alá. Az olyan szervezetekben, amelyekre nem jellemző a pedagógusok kreatív szakmai tanulásának támogatása, kevésbé gyakori az innovációk megjelenése, csupán egy-egy elszigetelt újítás csendes kikísérletezése elképzelhető. Ez pedig intézményi szinten aligha vezethet kaotikus állapotokhoz. Az innovációk okozta zürzavar tehát a szervezetek múködése szempontjából inkább elméleti, mintsem gyakorlati problémának tűnik.

Az oktatási innovációk kutatása során felmerült újabb fontos dilemmát a terület kutathatósága adta. Komoly szakmai vitákat indított el, hogy vajon mennyire gondoljuk empirikus eszközökkel megragadhatónak a helyi innovációk területét. Itt egyfelől kérdésként merül fel, hogy miként értelmezzük az új megoldások innovatív jellegét. Az újszerüséget abszolút értelemben, vagy pedig a helyi kontex- 
tus függvényében vizsgáljuk. Azaz amikor innovációkról beszélünk, feltétlenül olyan újításokra gondolunk-e, amelyek az egész oktatási rendszerre nézve, vagy akár nemzetközi vonatkozásban is innovatívak, netán megelégszünk azzal, ha az eljárás adott pedagógus gyakorlatában kísérletező tanulás eredményeképp jött létre. Meglátásom szerint az innovációk kutatása a gyakorlatban csak az utóbbi perspektívából képzelhető el, tekintettel arra, hogy a létező gyakorlatok számbavétele lehetetlen vállalkozásnak tűnik. Ugyanakkor felmerül a kérdés, hogy az innovációktól elvárjuk-e, hogy illeszkedjenek a korszerű pedagógiai megközelítésekhez, illetve a modern (jellemzően digitális) oktatási eszközök alkalmazásához. A korszerű megoldásokhoz kapcsolódó helyi fejlesztések esetében felerősödik egy másik fontos kérdés az innovációk kutathatósága szempontjából, amely a „tulajdonos” vagy az „eredetiség” problémájából adódik: Vajon egy adaptált, de erősen a helyi igényekhez igazított jó gyakorlat nevezhető-e helyi megoldásnak, és ha igen, mekkora változtatás után tehető ez? Az itt felmerülő kérdések olyan kritikus pontokat érintenek, amelyek esettanulmányok során, mély és minőségi adatgyüjtéssel ugyan feloldhatók, nagymintán, kérdőíves adatfelvétel esetében azonban komoly kihívást jelent a kezelésük.

Bár - mint láthatjuk - a helyi újítások tudományos értelmezése és empirikus megragadása számos bizonytalanságot hordoz még magában, a mindennapi szervezeti működés és a pedagógiai munka gyakorlata szempontjából ezek nem tűnnek igazán meghatározó kérdésnek. Fontosnak egyedül a pedagógusok problémamegoldó vagy általánosan modernizáló tanulásának megvalósulása látszik. Az innovációk, legyenek azok „adaptált” vagy „saját szülésü”, „forradalmasító” vagy „az újítók után lassan kullogó” megoldások, mind a kreatív munkahelyi tanulás produktumai. Olyan tevékenységek megvalósulásáról tanúskodnak, amelyek a helyi folyamatok jobbítására irányulnak. A hangsúly ezen kell, hogy legyen. A pedagógusok újító, problémamegoldó tevékenysége az, amely képes lehet a panaszkultúra helyébe lépve az intézményi működés eredményességének és versenyképességének növekedését támogatni.

Éppen ezért fontos, hogy a szabályozási keretek, illetve a külső fejlesztések teret és támogatást adjanak a pedagógusok és az iskolák újító tevékenységének. Utóbbiakra az elmúlt mintegy húsz évben számos példa volt hazánkban is, minek nyomán a kapcsolódó fejlesztési tudás egyre professzionálisabb lett mind a központi menedzsment, mind pedig a megvalósító iskolák körében. E fejlesztések a tanári tanulásról való mai tudásunkkal összhangban, egyre nagyobb hangsúlyt 
helyeztek a horizontális tanulásra, a tanulószervezeti környezetek kialakítására. Azaz olyan társas kapcsolatok müködtetése került előtérbe, amelyek kiemelten támogatják az újszerü megoldások születését és terjedését, illetve amelyek a kísérletező gyakorlatot tudják olyan komplex rendszerként müködtetni, amely nem csap át egy kaotikusnak nevezhető állapotba. Talán érdemes itt megemlíteni: azok a központi oktatásfejlesztések, amelyek a helyi szintű innovációk születéstét és terjedését támogatják, szükségszerűen olyan fejlesztési koncepcióra épülnek, amely összekapcsolja a pedagógusok adaptív (implementáló) és kreatív (innováló) tanulását. Az ilyen ösztönzésre létrejött innovációproduktumokról sokszor nehezen dönthető el, hogy inkább adaptált, vagy inkább saját fejlesztésként értelmezhetőek. Mindezek mellett a kérdés továbbra is fennáll: Vajon miként lehet az újitások jellemzőit, az újitásokat átvevó, fejlesztő pedagógusok sajátosságait, illetve azt a szervezeti- és rendszerkörnyezetet jobban megragadni, amelyben az oktatási innovációk keletkeznek és terjednek?

Bár a fent említett példákból is jól látszik, hogy a hazai fejlesztési gyakorlat az elmúlt két évtizedben számos területen jól tudta támogatni a pedagógusok tanulását, néhány terület továbbra is problémásnak látszik. Ilyen például az egyes szervezetek túlzott terhelése, mely egyaránt érintheti a mennyiségi és a tartalmi területet is. A fejlesztések megvalósításához szükséges szakmai és fejlesztési tudás sokszor nem áll rendelkezésre az intézményekben. Némelyik iskolában pedig éppen a tantestületet elárasztó fejlesztések hatására blokkolódik véglegesen a tanári tanulás, illetve az új megoldásokkal való kísérletezés. Mindez megfelelő fejlesztési tudással, az abszorpciós kapacitás figyelembevételével menedzselhető kérdés. Kevésbé kezelhető problémának tünik azonban az az esettanulmányok során jól megfigyelhető jelenség, amikor a pedagógusok komoly kognitív váltásai után, a legelőremutatóbb szakmai megoldások alkalmazása mellett is szorongó diákok ülnek a padokban. Az iskolákat járva, innovatív megoldásokat figyelve jól látható: az interperszonális kapcsolatok minőségére sok esetben nem tudnak hatást gyakorolni az innovatív pedagógiai eljárások, még akkor sem, ha a pedagógusok mélyen hisznek a gyermekek tevékenykedtetését középpontba helyező megoldásokban. Bár e probléma időről időre megfogalmazódik, és feloldására intézményi szinten vannak próbálkozások, átfogó kezelési lehetőség sem rendszer, sem pedig intézményi szinten nem látszik elérhetőnek jelenleg. 